DOI 10.37882/2223-2982.2021.12.38

\title{
КОГНИТИВНЫЙ АСПЕКТ СЕМАНТИКИ БЕСПРИСТАВОЧНЫХ ГЛАГОЛОВ ДВИЖЕНИЯ (НА МАТЕРИАЛЕ РУССКИХ НАРОДНЫХ ПЕСЕН)
}

\section{COGNITIVE ASPECT OF SEMANTICS OF VERBS OF MOTION OF NON-PREFIX VERBS (BASED ON RUSSIAN FOLK SONGS) \\ Zheng Zhongyi}

Summary: As we all know, verbs of motion in any language are frequently used. They have important information functions in oral and written communication. This paper introduces the most important characteristic elements of non-prefix verbs of motion - motion mode and directionality to be able to determine the space environment and movement direction in space; The use of unidirectional and multidirectional motion verbs is given; The lyrics of Russian songs are used as illustration materials to attract students' interest; This paper analyzes the usage of non-prefix verbs of motion on the ехаmple of идти-ходить taking the observer's posture; Considering their direct and transferred meanings in the context and their combination with different nouns called land transport, water vehicles, etc.

Keywords: Russian, verbs of motion, semantic, mode, directionality, Russian songs.

\author{
Чжэн Чжуньи \\ Аспирант, ассистент, Казанский \\ федеральный университет \\ zhongyi2017@mail.ru
}

Аннотация: Как известно, глаголы движения в любом языке являются частотными в употреблении. Они несут важную информационную функцию в разговорной речи и письменной коммуникации. В данной статье представлены самые важные характерные элементы бесприставочных глаголов движения - способ движения и направленность, которые позволяют определить среду и направление движения в пространстве; приведены факты употребления однонаправленных и разнонаправленных глаголов движения; тексты русских песен использованы в качестве иллюстративного материала, чтобы заинтересовать обучающихся; проанализированы употребления бесприставочных глаголов движения на примере идти-ходить при помощи позиции наблюдателя; рассмотрено использование глаголов движения в прямом и переносном значении в контексте, в частности в их сочетаемости с разными существительными, называющими средства сухопутного транспорта, средства движения по воде и т.д.

Ключевые слова: русский язык, глаголы движения, семантика, способ, направленность, русские песни.

[1974]; Гак В.Г. [1974, 1977]; Ибрагимова В.Л. [1975]; Мухамед А.М. [1984]; Псянчин Ю.В. [1990]; Журавлева О. Н. [1999]; Зарецкая С. А. [1999]; Майсак Т. А. [2002]; Падучева Е.В. [2002]; Валгина Н.С. и соавторы [2002]; Шайхисламова Г.3. [2012] и мн. др.).

Некоторые исследователи ведут дискуссию о парных глаголах движения, которые присутствуют в русском языке. Стоит отметить, что А.В.Исаченко обращает внимание на то, что «глаголы движения представлены 17 соотносительными парами: бежать-бегать, везти - возить, гнать - гонять, гнаться - гоняться, examb - ездить, идmu - ходить, катить - катать, катиться - кататься, лезть - лазить, лететь - леmamb, нести - носить, нестись - носиться, плыть плавать, ползти - ползать, тащить - таскать, тащиться - таскаться, вести - водить» [Исаченко, с. 576]. Так же есть еще несколько ученых-лингвистов, которые представляют нашему вниманию аналогичные бесприставочные глаголы движения в русском языке, которые описаны в «Русской грамматике-80», а именно: указанные выше 17 количественных пар с добавлением пары брести - бродить.

Далее дискуссионным остается вопрос о разграниче- 
нии понятий «движение» и «перемещение» в процессе изучении русских глаголов движения. Глаголы движения-перемещения с научной точки зрения являются те глаголы, которые обозначают перемещение в пространстве (именно физическое), то есть это живое и не живое. На самом деле, в современном русском языке можно найти несколько терминов по данному вопросу, то есть глаголы движения и глаголы перемещения чаще всего употребляются как синонимы, но иногда бывает такое, что глаголы перемещения могут входить в группу глаголов движения. Так же в некоторых исследовательских работах данные понятия объединяют в единое целое: «глаголы движения-перемещения». Кроме того, понятие слова «движение» в «Толковом словаре русского языка» понимается как «перемещение кого-чего-н. в определенном направлении» [Ожегов, с. 173] и в «Большом толковом словаре русского языка» объясняется слово «движение» как «перемещение в пространстве, в каком-л. направлении» или «перемещение чего-л. из одной инстанции в другую» [Кузнецов, с. 288], соответственно, понятие слова «движение», по их мнению, совпадает с словом «перемещение» в большинстве случаев.

Мы разделяем точку зрения А.А. Шахаевой и многих других лингвистов, которые считают, что различие между данными терминами не принципиальны [Шахаева, с. 118-123], т.е. понятия «движения» и «перемещения» равнозначны, поэтому в нашем исследовании используется популярный вариант «глаголы движения».

Способ движения и направленность являются самыми важными характерными элементами русских глаголов движения. Т. Майсак и другие ученые (В. Виноградова 1960, Т. Матиассен 1996, Т. Нессет 2010 и т. д.) считают, что способ движения и направленность отделяет глаголы движения от другой массы глаголов русского языка.

Способ движения иллюстрирует движение субъекта или объекта в пространстве, а направленность характеризует направление данного движения субъекта или объекта в пространстве, без которых мы не можем дифференцировать и воспринимать информацию о позиции движения, и также о том, что именно означает глагол движения в конкретном предложении.

По словам Н.К. Дмитриева, «все глаголы движения можно разделить на две группы: 1) глаголы, обозначающие направление движения; 2) глаголы, обозначающие способ движения» [Шайхисламова, т. 17, с. 1610-1614]. При изучении способа движения необходимо конкретизировать среду, в которой осуществляется действие: земля, вода или воздух. В данной статье представляется конкретное выделение способов движения у таких глаголов, как: 1) движение по земле а) пешком: идти - ходить, бежать - бегать, тащить - таскать и др.; б) на транспортном средстве: ехать - ездить, катить - каmaть и др.; 2) движение по воздуху: лететь - летать; 3) движение по воде: плыть - плавать.
Кроме того, глаголы движения противопоставляются по признаку направленности. Согласно А.В. Величко, «глаголы движения в русском языке делятся на основе

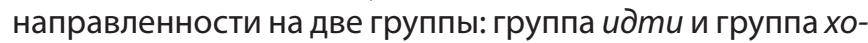
дumь [Величко, с. 511]. Глаголы группы идти называются глаголами однонаправленного движения и обозначают только однонаправленное поступательное движение от точки А к точке Б. Глаголы группы ходить, по словам А.В. Величко, нейтральны по отношению к признаку однонаправленности, они не выражают его прямо, эксплицитно, но и не противоречат ему. Эти глаголы получили название глаголов неоднонаправленного движения» [Величко, с. 511]. Однонаправленные глаголы (идти, examb, лететь и др.) употребляются в следующих ситуациях (примеры взяты из текстов русских песен):

1. Означают конкретное движение, при котором субъект стремится к движению конечной цели: Впереди солдат идет («Ах, ты зимушка, зима») [РНП];

2. Означают единичное движение в момент речи: Голубчик мой, Ванюшка, куда едешь ты? («Голубчик мой, Ванюшка») [РНП];

3. Означают конкретное единичное указание, просьба, приказ: Ты беги, беги по дорожке вдоль По дорожке вдоль, к отцу, к матери («Уж ты, поле мое, поле чистое») [РНП];

4. Означают повторяющееся однонаправленное движение, которое произошло до момента речи: Шел я и в ночь И средь белого дня («Славное море - священный Байкал») [РНП].

А разнонаправленные глаголы (бегать, плавать, носить и под.) имеют следующие характеристики при употреблении:

1. Обозначают движение как повторяющееся и неоднократное «движение в определенном направлении» и «движение обратно»: Офицер часто ходил На окошечко глядел («Барыня, барыня, сударыня барыня!») [РНП];

2. Обозначают движение как процесс перемещения субъекта в пространстве без указания на направление: Я с двенадцати лет по людям ходила («Уродилась я») [РНП];

3. Обозначают движение «туда» и «обратно»: В воскресенье я на ярмарку ходила («Неделька») [РНП];

4. Обозначают движение как способность или умение субъекта к перемещению: Что ты ко мне редко ходишь («Голубь, голубь, голубинька») [РНП].

Особенный интерес для исследования представляет семантическая часть глаголов, это связано с тем, что глагол, по мнению В. В. Виноградова, является «... самой сложной и самой емкой грамматической категорией русского языка. Глагол наиболее конструктивен по сравнению со всеми другими категориями частей речи. Глагольные конструкции имеют решающее влияние на именные словосочетания и предложения» [Виноградов, с. 422].

Из-за того, что существует лексико-семантической 
сложность русских глаголов движения, поэтому часто возникают речевые ошибки в их употреблении, особые трудности испытывают иностранные учащиеся в коммуникации. В данном исследовании мы обратимся к анализу использования бесприставочных глаголов движения, в частности глаголов: идти - ходить в русских песнях.

Некоторые ученые подчеркивают, что «в качестве ведущих членов группы глаголов движения рассматриваются коррелятивные глаголы идти и ходить. Эти глаголы обладают наибольшим количеством употребительных лексико-семантических вариантов, они обладают развернутой семантической системой, широкой сочетаемостью, они наиболее нейтральны стилистически, коммуникативно, грамматически, просодически и т.п., что ставит их в центр всей группы глаголов движения» [Шайхисламова, т. 17, с. 1610-1614].

При знакомстве с глаголом идти надо объяснить, что это однонаправленный глагол. Глаголы группы идти в настоящем времени обозначают либо единичное или конкретное движение, при котором субъект стремится к достижению конечной цели, например, Серый селезень плывет Добрый молодец идет («Вдаль да по речке») $[\mathrm{PH}]$, либо единичное движение, которое обозначает движение в момент речи: Вот кто-то с горочки спустился Наверно, милый мой идет («Вот кто-то с горочки спустился») [РНП].

Надо отметить, что в повелительном наклонении формы глагола также обозначают единичное, конкретное указание, просьбу или приказ: Иди с нивушки домой («Обрядовые песни осени») [РНП]. А в прошедшем времени они обозначают повторяющееся направленное движение, которое произошло до момента речи: Мимо тех ли ведь палат шла дорожка хороша («Барыня, Барыня, сударыня барыня!») [РНП] и единичное направленное движение, которое предстоит в ближайшем будущем: Мы не сами-то идем Нас нужда ведет («Ты взойди, солнце красное») [РНП].

По словам Б.В. Куриленко, «глагол ходить обычно употребляется в настоящем времени и обозначает повторяющееся разнонаправленное движение. Повторяемость часто подкрепляется словами каждый день, всегда, обычно, иногда и т. д.». [Куриленко, т. 4, с. 14-20]. Глаголы группы ходить в настоящем времени обозначают движение как повторяющееся и неоднократное: «движение в определенном направлении» и «движение обратно»: Что не ходишь, что не жалуешь ко мне («Посею лебеду на берегу») [РНП], кроме того, они в настоящем времени еще могут означать перемещение как умение, способность или привычка субъекта, например: Не ходить бы красной девке Что порой ходит («Чернобровый черноокий») [РНП]. В прошедшем времени они обычно обозначают движение без какой-либо направленности, то есть это представлено просто как процесс движения субъекта в пространстве: По той по дороженьке офицер часто ходил Офицер часто ходил, на окошечко глядел («Барыня, Барыня, сударыня барыня!») [РНП], или перемещение, состоящее из этапов «туда» и «обратно»: В воскресенье я на ярмарку ходила А во вторник я в банюшку ходила («Неделька») [РНП].

Яркой особенностью русских бесприставочных глаголов движения однонаправленного и разнонаправленного движения таких, как идти - ходить является то, что они часто могут использоваться в переносном смысле, семантические связанном с понятием перемещения: «время идет», «осень идет», «урок идет», «часы идут медленно», «дождь идет целый день», «идут за днями дни», «ходить по головам», «под стол ходить» и т.д., а в примерах, подобных этому: «эта футболка тебе идет» - лексема «идет» совпадает со значением слова «подходить», см. Словарь Ожегова С.И.: «(1 и 2 л. не употр.), кому-чему и к чему. Быть к лицу, подходить. Шляпа тебе не идет (не идет к лицу). Ей не идет кокетничать» [Ожегов, с. 66].

Важной характеристикой глаголов идти - ходить в речевом употреблении является то, что именно они регулярно употребляются и сочетаются с существительными, обозначающимися средства сухопутного транспорта такие, как: автобус, троллейбус, трамвай, поезд и средства передвижения по воде такие, как: лодка, яхта, корабль и др., например, «автобус всегда ходит по расписанию», «поезд ходит очень быстро», «трамваи ходят медленно», «лодка идет к берегу», «яхта идет по волнам», «корабль идет на юг» и т.д.

Таким образом, проанализировав случаи употребления бесприставочных глаголов движения на материале русских песен, мы можем сделать следующие выводы:

1. Способ движения иллюстрирует движение субъекта или объекта в пространстве, а направленность характеризует валентность данного движения, соответственно, надо обращать особое внимание на этот аспект при знакомстве с русскими глаголами движения.

2. При изучении русских бесприставочных глаголов движения первоначально необходимо познакомиться с частотными глаголами данной группы, такими как: идти - ходить, проиллюстрировать их использование в речи на материале, например, русских народных песен, чтобы заинтересовать обучающихся.

3. Глаголы движения многозначны и широко употребляются в переносном значении, следовательно, для правильной оценки их семантики необходимо выделять и уточнять их конкретные значения в контексте или в их сочетаемостях с разными существительными, называющими средства сухопутного транспорта, средства движения по воде и т.д. 
ЛИТЕРАТУРА

1. Ванюгина С.М. Сочетаемость приставочных глаголов движения в современном русском языке: корпусное и экспериментальное изучение: диссертация ... кандидата филологических наук: 10.02.01. - Череповец, 2010. - 141 с.

2. Величко В.А. Книга о грамматике (Русский язык как иностранный). 3-е издание, направленное и дополненное. - М: Издательство Московского университета, 2009. - 511 c.

3. Виноградов В.В. Русский язык. Грамматическое учение о слове. - М: - JL, 1947. - 422 с.

4. Исаченко В.А. Грамматический строй русского языка в сопоставлении с словацким: Морфология. Раздел «Глаголы перемещения». - Братислава: Словацкая акад. наук, 1960. -576 с.

5. Кузнецов А.С. Большой толковый словарь русского языка. - Санкт-Петербург., 1998.

6. Куриленко Б.В., Щербакова М.О., Бирюкова Н.Ю. Глаголы движения: стратегии обучения на начальном этапе: Образовательный вестник «Сознание». М: Российский университет дружбы народов»: 2018. - Том 4. - 14-20 с.

7. Ожегов И.С., Шведова Ю.Н. Толковый словарь русского языка: 80000 слов и фразеологических выражений. - М: 000 «А ТЕМП», 2006.

8. РНП - Русские народные песни [Электронный ресурс]. - Режим доступа: http://pesni.retroportal.ru/np.shtml (дата обращения: 25.10.2021).

9. Шайхисламова Г.З. История изучения глаголов движения в разносистемных языках. - Уфа : Вестник Башкирского университета. - 2012. - (1): Том 3.

10. Шахаева А.А. К вопросу о выделении лексико-семантической группы глаголов движения в китайском и бурятском языках // Философия. - Улан-Удэ: Вестник Бурятского государственного университета. - 2011. - С. 118-123.

(c) Чжэн Чжуньи (zhongyi2017@mail.ru).

Журнал «Современная наука: актуальные проблемы теории и практики»

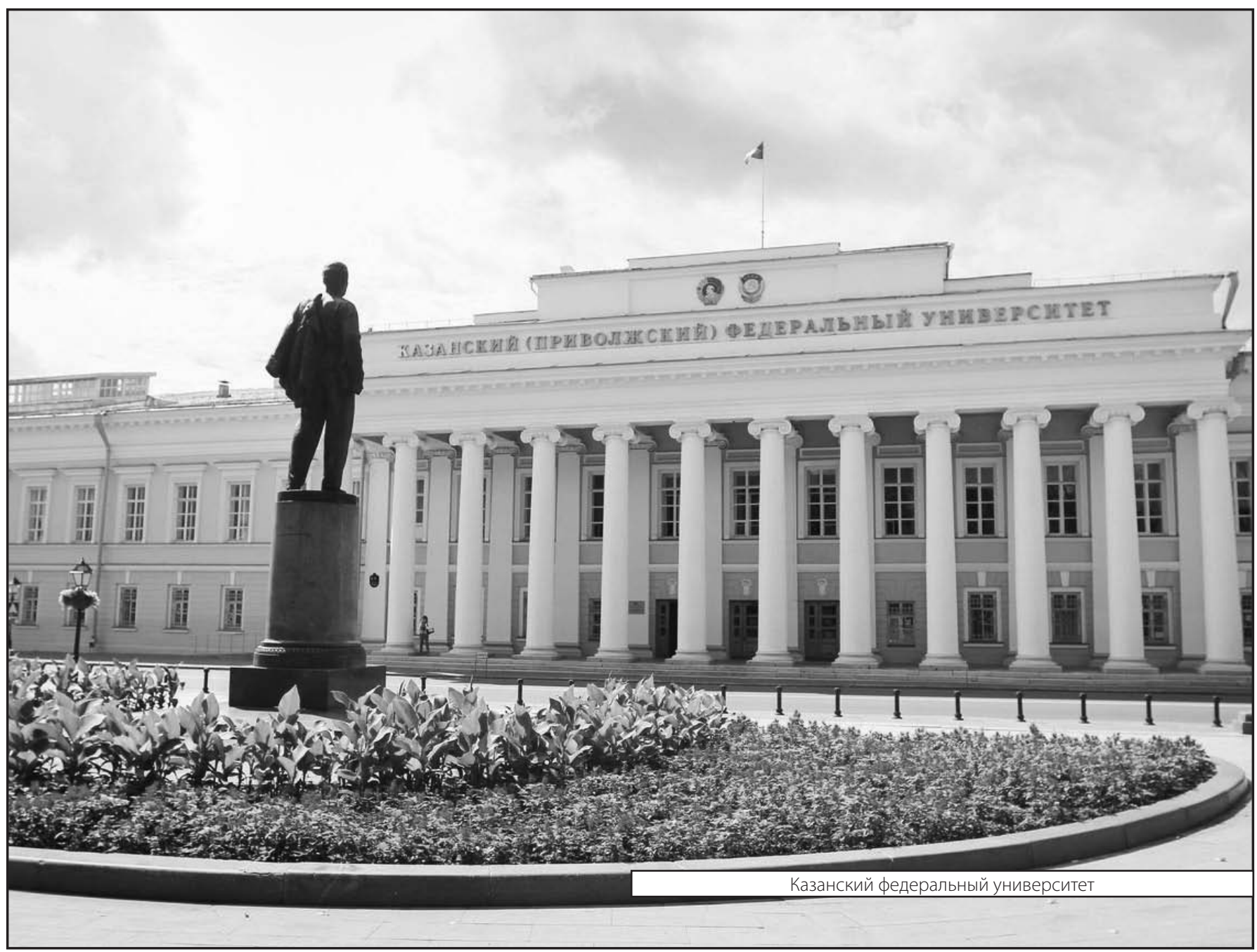

